\title{
Triple-Negative Breast Carcinoma
}

National Cancer Institute

\section{Source}

National Cancer Institute. Triple-Negative Breast Carcinoma. NCI Thesaurus. Code C71732.

An invasive breast carcinoma which is negative for expression of estrogen receptor (ER), progesterone receptor (PR), and human epidermal growth factor receptor 2 (HER2). 